\title{
Glucose Production and Oxidation in Preterm Infants during Total Parenteral Nutrition ${ }^{1}$
}

\author{
HARRY N. LAFEBER, ERIC J. SULKERS, THOMAS E. CHAPMAN, AND PIETER J. J. SAUER \\ Department of Pediatrics, Division of Neonatology, Erasmus University Rotterdam, University Hospital/Sophia \\ Children's Hospital, Rotterdam, The Netherlands [H.N.L., E.J.S., P.J.J.S.] and Department of Pediatrics, \\ Research Laboratory, University of Groningen, Groningen, The Netherlands [T.E.C.]
}

\begin{abstract}
During total parenteral nutrition in preterm infants, glucose may be infused at high rates, but it is not known if the endogenous glucose production is fully suppressed under these circumstances. Eight preterm appropriate for gestational age (AGA) (birth wt: $1613 \pm 151 \mathrm{~g}$, gestational age: $31.1 \pm 1.5 \mathrm{wk}$ ) and eight preterm small for gestational age (SGA) newborn infants $(1185 \pm 241 \mathrm{~g}$, $32.9 \pm 2.6 \mathrm{wk})$ receiving a glucose infusion rate of $7.55 \pm$ 0.56 and $8.16 \pm 0.65 \mathrm{mg} / \mathrm{kg} \cdot \mathrm{min}$, respectively, were studied during continuous total parenteral nutrition at postnatal d 8. Glucose oxidation rate was determined with a primed constant infusion of $\left[\mathrm{U}^{13} \mathrm{C}\right]$ glucose, measuring the ${ }^{13} \mathrm{CO}_{2}$ production in breath gas by isotope ratio mass spectrometry and the glucose production rate in plasma by gas chromatography mass spectrometry. In breath gas of AGA and SGA infants, 60 and $65 \%$, respectively, of the infused tracer appeared as ${ }^{13} \mathrm{CO}_{2}$. The glucose production rates were $7.97 \pm 1.61$ and $8.12 \pm 1.84 \mathrm{mg} / \mathrm{kg} \cdot \mathrm{min}$ in $\mathrm{AGA}$ and SGA infants, respectively, indicating that no significant endogenous glucose production occurred. The glucose oxidation calculated from the glucose production and ${ }^{13} \mathrm{CO}_{2}$ production was $4.74 \pm 0.99 \mathrm{mg} / \mathrm{kg} \cdot \mathrm{min}$ in AGA infants and was significantly different from the carbohydrate oxidation rate of $6.62 \pm 1.23 \mathrm{mg} / \mathrm{kg} \cdot \min$ measured by simultaneous indirect calorimetry. In SGA infants, however, the glucose and carbohydrate oxidation rates were not significantly different at $5.33 \pm 1.56$ and $6.16 \pm 2.45 \mathrm{mg} / \mathrm{kg}$. min. It is concluded that 1-wk-old AGA or SGA preterm infants receiving total parenteral nutrition of $80 \mathrm{kcal} / \mathrm{kg} \cdot \mathrm{d}$ produce no endogenous glucose and their glucose oxidation rates are similar at $\mathbf{6 3 - 6 5 \%}$ of the glucose infused. It is suggested that the significant difference between glucose and carbohydrate oxidation rates observed in AGA but not in SGA infants is due either to a higher rate of lipogenesis from carbohydrates, or, less likely, to a higher rate of glycogen oxidation. (Pediatr Res 28: 153-157, 1990)
\end{abstract}

\section{Abbreviations}

AGA, appropriate for gestational age

$R_{\mathrm{a}}$, rate of glucose appearance in plasma

$R Q$, respiratory quotient

SGA, small for gestational age

TPN, total parenteral nutrition

Received December 5, 1989; accepted March 30, 1990.

Correspondence and reprint requests: Dr. H. N. Lafeber, Department of Pediatrics, Division of Neonatology, Erasmus University Rotterdam, University Hospital/Sophia Children's Hospital, Gordelweg 160, 3038 GE Rotterdam. The Netherlands.

Supported in part by NWO Grant 900-528-057 and grants from the Sophia Foundation for Medical Research. Rotterdam. The Netherlands and Fresenius A.G., Bad Homburg. FRG

Presented in part at the meeting of the European Society for Pediatric Research, June 1988, Oslo Norway (Pediatr Res 24:273, 1988)
$\mathrm{VCO}_{2}$, carbon dioxide production

$\mathrm{VO}_{2}$, oxygen consumption

During TPN, a substantial part of the energy is provided by glucose. In preterm newborn infants, many unanswered questions exist regarding the metabolic responses to glucose infusion. In adults, glucose infusion results in a suppression of the endogenous glucose production (1). If the glucose infusion rate is increased in these adults, the oxidation rate also increases to a maximum (1). In preterm and term infants, glucose is often infused at higher rates than in adults and it is not known whether the glucose oxidation rate may be limited. In term infants, a glucose infusion rate exceeding the maximal glucose oxidation rate may result in lipogenesis from glucose, causing a rise in metabolic rate and in RQ (2). In a previous study in term newborn infants receiving glucose and amino acids parenterally, glucose oxidation rates were measured with a combination of indirect calorimetry and $\left[\mathrm{U}_{-}{ }^{13} \mathrm{C}\right]$ glucose tracer methodology (2). Glucose infusions of $10-15 \mathrm{mg} / \mathrm{kg} \cdot \min$ were given and glucose oxidation was calculated with the assumption that under these circumstances no glucose is endogenously produced. This assumption, however, ignores the fact that the suppression of the endogenous glucose production may be incomplete or variable. In a study using $\left[\mathrm{U}-{ }^{13} \mathrm{C}\right]$ glucose as a tracer, it was found that endogenous production was still present during i.v. infusion of glucose at $6 \mathrm{mg} / \mathrm{kg} \cdot \mathrm{min}$ in both SGA and AGA term infants (3). Using a glucose clamp technique, other investigators found no evidence for endogenous production during a glucose infusion of $8.7 \mathrm{mg} / \mathrm{kg} \cdot \mathrm{min}$ in preterm AGA infants (4). To investigate to what extent continuous glucose infusion, in addition to lipids and amino acids, influences the endogenous glucose production and glucose oxidation in preterm AGA and SGA infants after 1 wk of life, we studied these parameters by combining indirect calorimetry with $\left[\mathrm{U}-{ }^{13} \mathrm{C}\right.$ ]glucose infusion and measurement of ${ }^{13} \mathrm{CO}_{2}$ production in expiratory air, and by also determining the endogenous glucose production by measuring the plasma dilution of $\left[\mathrm{U}-{ }^{13} \mathrm{C}\right]$ glucose, enabling us to calculate the glucose oxidation from exogenous and endogenous sources.

\section{PATIENTS AND METHODS}

Patients. Eight AGA and eight SGA preterm newborn infants were studied. AGA was defined as a birth wt within $2 \mathrm{SD}$ of the mean for gestation, according to the growth curves of Usher and McLean (5). SGA was defined as a birth wt more than 2 SD below the mean. Gestational age was determined by medical history and Ballard score (6). Only infants with a birth wt of less than $1600 \mathrm{~g}$ were included in the study. All infants were initially admitted to the Neonatal Intensive Care Unit of the University Hospital Rotterdam/Sophia Children's Hospital. At the time of 
the study, all infants were clinically stable and were breathing room air. Mean birth wt, gestational age, and wt at the day of study are shown in Table 1 .

$T P N$. All infants received TPN by an indwelling peripheral vein cannula from d 2 on because of an increased risk for necrotizing enterocolitis when fed orally during the first days of life (7). Glucose, combined with minerals and trace elements (4 $\mathrm{mL} / \mathrm{kg} \cdot \mathrm{d}$; Pedel, Kabi, Stockholm, Sweden) was administered from birth. Once daily, $0.5 \mathrm{~mL} / \mathrm{kg}$ of soluble vitamins (Soluvit, Kabi) was given i.v. Fat was given from d 2 on using a soybean emulsion (Intralipid 10\%, Kabi) mixed with fat soluble vitamins $0.1 \mathrm{~mL} / \mathrm{kg} \cdot \mathrm{d}$ (Vitalipid, Kabi). Protein was given from d 2 on using an amino acid solution (Aminovenös 10\%, Fresenius, Bad Homburg, FRG). For all the infusions, the same type of syringe pump was used (Perfusor Secura GT, Braun, Melsungen, FRG). From d 3 on, and therefore also during the studies performed at $\mathrm{d} 8$, all infants received a continuous infusion of glucose, lipids, and amino acids $24 \mathrm{~h} / \mathrm{d}$ at a dosage shown in Table 2.

Study procedure. The study protocol was approved by the Human Subject Review Committee of the University Hospital Rotterdam. Written informed consent was obtained from the parents.

At d 8, indirect calorimetry was performed over 6 to $8 \mathrm{~h}$. During the indirect calorimetry, a primed constant infusion of $\left[\mathrm{U}-{ }^{13} \mathrm{C}\right]$ glucose was given; just before and during the infusion, expiratory air samples were collected from the closed circuit calorimeter. Before and at the end of the study, a venous blood sample was collected. Urine was collected for $72 \mathrm{~h}$ from the 7 th to the 9 th $\mathrm{d}$.

Indirect calorimetry. Metabolic rate and substrate use were measured by a closed circuit indirect calorimeter. Continuous measurements were performed for 6 to $8 \mathrm{~h}$, as previously described (8). Briefly, an air mixture devoid of $\mathrm{CO}_{2}$ enters the incubator. In a sample of the air leaving the incubator, the $\mathrm{CO}_{2}$ concentration is measured; thereafter all $\mathrm{CO}_{2}$ is filtered out by a soda-lime filter. $\mathrm{CO}_{2}$ is injected again into the air flow by a mass flow injector system until the same concentration of $\mathrm{CO}_{2}$ is measured by the infrared meter (Unor 6N, Maihak, Hamburg, FRG). The amount of $\mathrm{CO}_{2}$ injected into the system equals the $\mathrm{VCO}_{2}$ of the infant. Thereafter, all $\mathrm{CO}_{2}$ is filtered by a second soda-lime filter. The amount of oxygen consumed by the infant is equal to the amount of oxygen that has to be injected into the system to keep the oxygen tension constant, as measured by polarographic oxygen cells (type 6223771, Beckman, Fullerton,

Table 1. Clinical features of preterm infants studied at $d 8^{*}$

\begin{tabular}{cccc}
$\begin{array}{c}\text { Preterm infant } \\
\text { group }\end{array}$ & $\begin{array}{c}\text { Birth wt } \\
(\mathrm{g})\end{array}$ & $\begin{array}{c}\text { Gestational } \\
\text { age } \\
(\mathrm{wk})\end{array}$ & $\begin{array}{c}\text { Wt when } \\
\text { studied } \\
(\mathrm{g})\end{array}$ \\
\hline AGA $(n=8)$ & $1613 \pm 151$ & $31.1 \pm 1.5$ & $1610 \pm 193$ \\
SGA $(n=8)$ & $1185 \pm 241 \dagger$ & $32.9 \pm 2.6$ & $1173 \pm 259 \dagger$ \\
\hline
\end{tabular}

$*$ Values are expressed as means \pm SD.

$\dagger$ Differences between AGA and SGA infants are significant at $p<$ 0.005 (Wilcoxon).

Table 2. Composition and energy content of TPN*

\begin{tabular}{ccccc}
\hline $\begin{array}{c}\text { Preterm infant } \\
\text { group }\end{array}$ & $\begin{array}{c}\text { Caloric } \\
\text { intake } \\
(\mathrm{kcal} / \mathrm{kg} \cdot \mathrm{d})\end{array}$ & $\begin{array}{c}\text { Glucose } \\
\text { intake } \\
(\mathrm{g} / \mathrm{kg} \cdot \mathrm{d})\end{array}$ & $\begin{array}{c}\text { Fat intake } \\
(\mathrm{g} / \mathrm{kg} \cdot \mathrm{d})\end{array}$ & $\begin{array}{c}\text { Protein } \\
\text { intake } \\
(\mathrm{g} / \mathrm{kg} \cdot \mathrm{d})\end{array}$ \\
\hline $\mathrm{AGA}(n=8)$ & $74.0 \pm 3.1$ & $11.25 \pm 1.54$ & $2.35 \pm 0.08$ & $2.35 \pm 0.08$ \\
SGA $(n=8)$ & $79.0 \pm 3.5 \ddagger$ & $11.75 \pm 0.94$ & $2.47 \pm 0.09 \dagger 2.47 \pm 0.09 \dagger$ \\
\hline
\end{tabular}

$*$ Values are expressed as means \pm SD.

† Differences between AGA and SGA infants are significant at $p<$ 0.05 (Wilcoxon).

$\ddagger$ Differences between AGA and SGA infants are significant at $p<$ 0.01 (Wilcoxon)
CA) in the system and in a reference vessel. To compensate for changes in air pressure, the reference vessel is connected to the flow circuit by means of a capillary. The accuracy of the measurement of $\mathrm{VO}_{2}$ and $\mathrm{VCO}_{2}$ are tested by burning $99.8 \%$ pure butane. Measurements in the calorimeter were only performed if the RQ when burning $99.8 \%$ butane was within $2 \%$ of the theoretical value $(0.609 \pm 0.015)$. Urinary nitrogen concentration was determined in a pooled urine sample by combustion in an automatic nitrogen analyzer (ANA 1400, Carlo Erba, Milano, Italy) by the Dumas procedure (9). Nonprotein $\mathrm{VO}_{2}$ and nonprotein $\mathrm{VCO}_{2}$ were derived from the overall $\mathrm{VO}_{2}$ and $\mathrm{VCO}_{2}$ by correcting the values for the protein oxidation, calculated as 6.25 times the timed urinary nitrogen excretion. Nonprotein metabolic rate and partition of the nonprotein macro nutrients were calculated from nonprotein $\mathrm{RQ}$ and nonprotein $\mathrm{VO}_{2}$ using the tables of Lusk (10).

Breath gas analysis. Before infusion of the label, three baseline breath samples were collected during $15 \mathrm{~min}$ each for determination of the natural background of ${ }^{13} \mathrm{CO}_{2}$. Breath $\mathrm{CO}_{2}$ was collected by passing a sample of the air leaving the incubator through an all-glass spiral condensor containing $10 \mathrm{~mL}$ of fresh $1 \mathrm{M} \mathrm{NaOH}$. Samples were transferred to Vacutainers and stored at $-20^{\circ} \mathrm{C}$ until analysis. Trapping of $\mathrm{CO}_{2}$ was shown to be complete during $15 \mathrm{~min}$ at a flow of $10 \mathrm{~mL} / \mathrm{min}$ and, therefore, isotopic fractionation was prevented. The body bicarbonate pool was primed with $6.9 \mu \mathrm{mol} / \mathrm{kg}$ of $\mathrm{NaH}^{13} \mathrm{CO}_{3}(6.9 \mathrm{mmol} / \mathrm{L}$ solution) (MSD Isotopes, Dorval, Quebec, Canada) as previously described (11). At the same time, a $\left[\mathrm{U}-{ }^{13} \mathrm{C}\right]$ glucose solution of $3.0 \mathrm{mmol} / \mathrm{L}$ (98.9\% enriched, MSD Isotopes) was given as a priming dose of $0.80 \mathrm{mg} / \mathrm{kg}$, followed by a constant infusion of $0.45 \mathrm{mg} / \mathrm{kg} \cdot \mathrm{h}$ using a syringe pump (type as described above). All solutions were diluted in sterile water and tested for sterility. The delivery rate of the pump during the studies was measured by dividing the difference in weight of the syringe before and after the experiment by the duration to determine the actual quantity that was administered. Once the isotope infusion was started, 15-min $\mathrm{CO}_{2}$ breath samples were collected every hour for $4 \mathrm{~h}$, and every $30 \mathrm{~min}$ for 2 to 4 more $\mathrm{h}$. Before and at the end of the experiment, a plasma sample was collected and stored at $-20^{\circ} \mathrm{C}$.

Respiratory $\mathrm{CO}_{2}$ was liberated at $<10^{-3}$ torr by adding $85 \%$ phosphoric acid to the $\mathrm{NaHCO}_{3}$ solution. Pure $\mathrm{CO}_{2}$ was collected in a small glass container in liquid nitrogen, and the water was trapped in a methanol dry ice bath. The glass container with pure $\mathrm{CO}_{2}$ was connected to a VG Sira 10 isotope ratio mass spectrometer (VG Isotech Ltd., Middlewich, Cheshire, UK). Results of ${ }^{13} \mathrm{C}$ abundance of both baseline and plateau were calculated as atom percent excess against the reference tank $\mathrm{CO}_{2}$ standard sample.

Analysis of isotope dilution in plasma. To $50 \mu \mathrm{L}$ of plasma, methanol was added to precipitate proteins. The supernatant was washed with $5 \mathrm{~mL}$ hexane to remove the FFA. The methanol was evaporated to dryness. An aldonitrile pentacetate derivative was prepared according to Tserng and Kalhan (12); isotope dilution was measured by means of gas chromatography/mass spectrometry using chemical ionization with ammonia as the ionization gas. Isotope enrichment was measured by selective ion monitoring at the $\mathrm{M}+\mathrm{NH}_{4}{ }^{+}$ion at $\mathrm{m} / \mathrm{z} 405.2$ and $\mathrm{m} / \mathrm{z} 411.2$ for endogenous and $\left[\mathrm{U}-{ }^{13} \mathrm{C}\right]$-labeled glucose, respectively. The analysis was performed using a HP5890 gas chromatograph (Hewlett Packard, Co., Palo Alto, CA), coupled directly to a VG 70-250S magnetic sector mass spectrometer (VG Mass Lab Ltd. Altrincham, UK). For the determination of the enrichment of $\left[\mathrm{U}-{ }^{13} \mathrm{C}\right]$ glucose in plasma by means of gas chromatography/mass spectrometry and selective ion monitoring, a calibration graph was made of standard mixtures ranging from 0 to $0.15 \%\left[\mathrm{U}-{ }^{13} \mathrm{C}\right]$ glucose as shown in Figure 1. The coefficient of variation for measurements in triplicate ranged from 2 to $6 \%$. A similar calibration graph has been published previously by Chapman (13). 


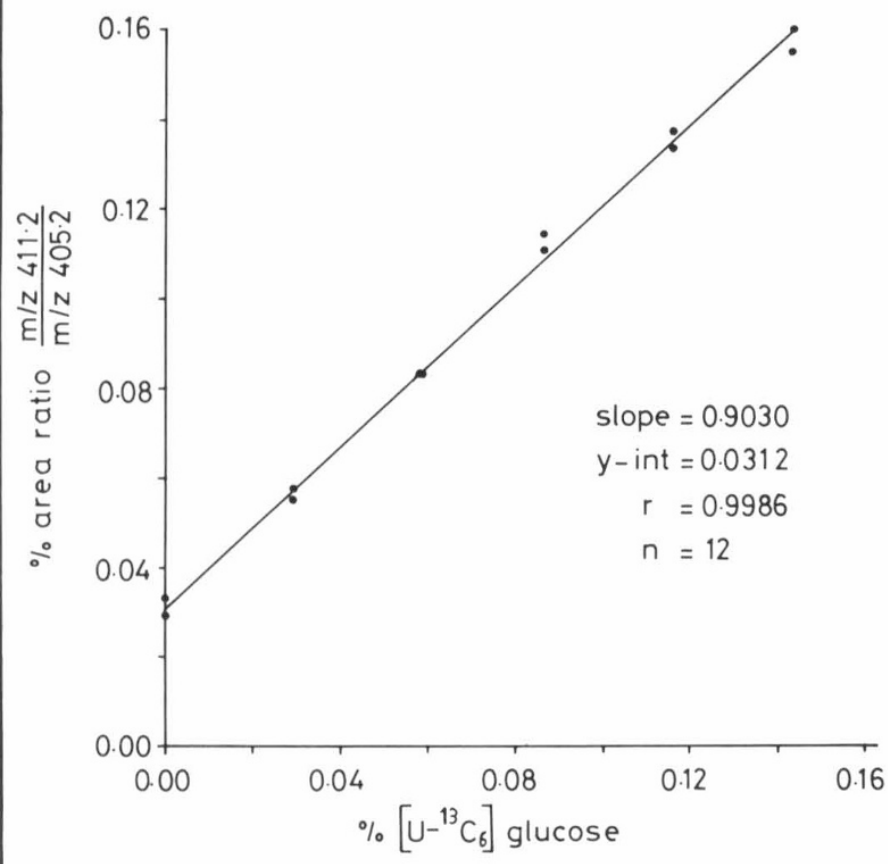

Fig. 1. Gas chromatography/mass spectrometry selective ion monitoring calibration graph used to measure the percentage $\left[\mathrm{U}-{ }^{13} \mathrm{C}\right]$ glucose enrichment in plasma.

Calculations. The fraction of ${ }^{13} \mathrm{C}$ glucose tracer recovered in $\mathrm{CO}_{2}$ was calculated as follows:

${ }^{13} \mathrm{CO}_{2}$ production $(\mu \mathrm{mol} / \mathrm{kg} \cdot \mathrm{h})$

$$
=\frac{\mathrm{VCO}_{2} \times 60}{22.4} \times \frac{\mathrm{h}}{100} \times \frac{100}{\mathrm{C}} \times 1000
$$

where $\mathrm{VCO}_{2}$ is expressed in $\mathrm{mL} / \mathrm{kg} \cdot \mathrm{min}, \mathrm{h}=$ plateau height ${ }^{13} \mathrm{CO}_{2}$ above baseline (atom percent excess), and $\mathrm{C}=$ correction factor for ${ }^{13} \mathrm{CO}_{2}$ retention in the bicarbonate pool, calculated from the energy intake of the infant (11).

\section{${ }^{13} \mathrm{C}$ administered $(\mu \mathrm{mol} / \mathrm{kg} \cdot \mathrm{h})$}

$$
=\left[\mathrm{U}-{ }^{13} \mathrm{C}\right] \text { glucose }(\mu \mathrm{mol} / \mathrm{kg} \cdot \mathrm{h}) \times 6 \times 0.989
$$

where 0.989 is the factor of enrichment of $\left[\mathrm{U}-{ }^{13} \mathrm{C}\right]$ glucose as determined by the manufacturer.

$$
{ }^{13} \mathrm{CO}_{2} \text { recovered }(\%)=\frac{{ }^{13} \mathrm{CO}_{2} \text { production }}{{ }^{13} \mathrm{C} \text { administered }} \times 100
$$

$\mathrm{R}_{\mathrm{a}}$ was calculated as follows:

$$
\begin{aligned}
& \mathrm{R}_{\mathrm{a}}(\mathrm{mg} / \mathrm{kg} \cdot \mathrm{min})= {\left[\frac{\left[0.989^{6}\right]}{\left[\mathrm{U}-{ }^{13} \mathrm{C}\right] \text { glucose enrichment plasma }}-1\right] } \\
& \quad \times\left[\mathrm{U}-{ }^{13} \mathrm{C}\right] \text { glucose infused }(\mathrm{mg} / \mathrm{kg} \cdot \mathrm{min})
\end{aligned}
$$

where $\left[0.989^{6}\right](=0.936)$ represents the $m+6$ enrichment of $98.9 \%\left[\mathrm{U}-{ }^{13} \mathrm{C}\right]$ glucose assuming that $98.9 \%$ of all $\mathrm{C}$ atoms are ${ }^{13} \mathrm{C}$.

The glucose oxidation rate from exogenous and endogenous glucose was calculated from the $\mathrm{R}_{\mathrm{a}}$ and the ${ }^{13} \mathrm{C}$ recovery (glucose oxidation $=\mathrm{R}_{\mathrm{a}} \times{ }^{13} \mathrm{C}$ recovery) in $\mathrm{mg} / \mathrm{kg} \cdot \mathrm{min}$. The glucose oxidation rate from exogenous glucose was calculated from the nonlabeled glucose infusion and the ${ }^{13} \mathrm{C}$ recovery (glucose oxidation $=$ glucose infusion rate $\times{ }^{13} \mathrm{C}$ recovery) in $\mathrm{mg} / \mathrm{kg} \cdot \mathrm{min}$.

The carbohydrate oxidation rate in $\mathrm{mg} / \mathrm{kg} \cdot \mathrm{min}$ was calculated from the nonprotein $\mathrm{RQ}$ and nonprotein $\mathrm{VO}_{2}$ according to the tables of Lusk (10):
Carbohydrate oxidation

$$
=\text { nonprotein } \mathrm{VO}_{2} \times \frac{(\text { nonprotein } \mathrm{RQ}-0.707)}{0.293 \times 746}
$$

where nonprotein $\mathrm{VO}_{2}$ is in $\mathrm{mL} / \mathrm{kg} \cdot \mathrm{min}$; (nonprotein $\mathrm{RQ}$ $0.707) / 0.293$ determines the fractional contribution of carbohydrate oxidation to the nonprotein $\mathrm{VO}_{2}$ and 746 represents $\mathrm{mL}$ of oxygen consumed/g of glucose oxidized.

All results are expressed as means \pm SD. Wilcoxon's TwoSample Rank Test was used for comparison of the measured variables of the patients.

\section{RESULTS}

The results of indirect calorimetry are shown in Table 3. None of the differences between SGA and AGA infants were significant. The production of ${ }^{13} \mathrm{CO}_{2}$ in expiratory air rose in the first hour in all patients and reached a plateau in all patients within 3 to $4 \mathrm{~h}$. An example of a characteristic study is shown in Figure 2.

The results of the isotopic studies are shown in Table 4. The $\mathrm{R}_{\mathrm{a}}$ calculated from plasma dilution of $\left[\mathrm{U}-{ }^{13} \mathrm{C}\right]$ glucose in the second plasma sample during the plateau in expiratory ${ }^{13} \mathrm{CO}_{2}$ was $7.97 \pm 1.61 \mathrm{mg} / \mathrm{kg} \cdot \mathrm{min}$ in AGA infants and $8.12 \pm 1.84$ $\mathrm{mg} / \mathrm{kg} \cdot \mathrm{min}$ in SGA infants. In comparison with the exogenous glucose intake, this indicates an endogenous glucose production of $0.42 \pm 1.65$ and $-0.04 \pm 1.90 \mathrm{mg} / \mathrm{kg} \cdot \mathrm{min}$ in AGA and SGA preterm infants, respectively, (neither rate is significantly differ-

\begin{tabular}{|c|c|c|c|c|}
\hline $\begin{array}{l}\text { Preterm infant } \\
\text { group }\end{array}$ & $\begin{array}{c}\text { Nonprotein } \\
\mathrm{VO}_{2} \\
(\mathrm{~mL} / \mathrm{kg} \cdot \mathrm{min})\end{array}$ & $\begin{array}{c}\text { Nonprotein } \\
\mathrm{VCO}_{2} \\
(\mathrm{~mL} / \mathrm{kg} \cdot \mathrm{min})\end{array}$ & $\begin{array}{l}\text { Nonprotein } \\
\text { RQ }\end{array}$ & $\begin{array}{c}\text { Nonprotein } \\
\text { metabolic rate } \\
(\mathrm{kcal} / \mathrm{kg} \cdot \mathrm{d})\end{array}$ \\
\hline $\operatorname{AGA}(n=8)$ & $5.83 \pm 0.82$ & $5.68 \pm 0.84$ & $0.97 \pm 0.04$ & $42.1 \pm 4.6$ \\
\hline $\mathrm{SGA}(n=8)$ & $6.44 \pm 1.15$ & $5.96 \pm 1.10$ & $0.93 \pm 0.08$ & $46.4 \pm 7.9$ \\
\hline
\end{tabular}
ent from 0).

The glucose oxidation rates calculated from the ${ }^{13} \mathrm{C}$ recovery in expiratory air were $4.51 \pm 1.13$ and $5.41 \pm 0.60 \mathrm{mg} / \mathrm{kg} \cdot \mathrm{min}$ for AGA and SGA infants, respectively, when based on the

Table 3. Results of closed circuit indirect calorimetry over $8 h^{*}$

$*$ Values are expressed as means \pm SD. None of the differences between AGA and SGA infants are significant (Wilcoxon).

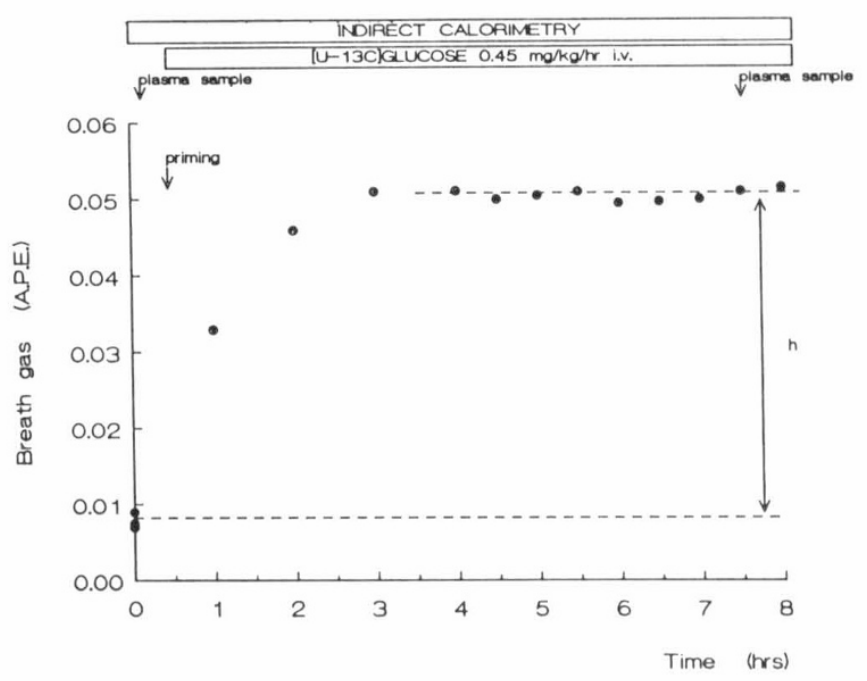

Fig. 2. Time course of ${ }^{13} \mathrm{CO}_{2}$ enrichment in breath after a primed $\left(6.9 \mu \mathrm{mol} / \mathrm{kg} \mathrm{NaH}{ }^{13} \mathrm{CO}_{3}\right.$ and $\left.0.80 \mathrm{mg} / \mathrm{kg}\left[\mathrm{U}-{ }^{13} \mathrm{C}\right] \mathrm{glucose}\right)$ constant i.v. infusion of $0.45 \mathrm{mg} / \mathrm{kg} \cdot \mathrm{hr}\left[\mathrm{U}-{ }^{13} \mathrm{C}\right] \mathrm{glucose}$ in one patient. Three baseline breath samples and one plasma sample were taken before the stable isotope administration and one plasma sample was taken during the plateau in breath ${ }^{13} \mathrm{CO}_{2}$ at the end of the experiment. 
Table 4. Glucose intake, $R_{a}$, glucose oxidation calculated from exogenous glucose infusion and from $R_{a}$, and carbohydrate oxidation calculated from indirect calorimetry in $\mathrm{mg} / \mathrm{kg} \cdot \mathrm{min}^{*}$

\begin{tabular}{|c|c|c|c|c|c|c|}
\hline $\begin{array}{l}\text { Preterm infant } \\
\text { group }\end{array}$ & $\begin{array}{l}\text { A } \\
\text { Exogenous } \\
\text { glucose } \\
\text { infusion }\end{array}$ & $\begin{array}{l}\mathrm{B} \\
\mathrm{R}_{a}\end{array}$ & $\begin{array}{c}\text { C } \\
\text { Endogenous } \\
\text { glucose production } \\
(\mathrm{B}-\mathrm{A})\end{array}$ & $\begin{array}{c}\text { D } \\
\text { Glucose } \\
\text { oxidation } \\
\text { (from A) }\end{array}$ & $\begin{array}{c}\text { E } \\
\text { Glucose } \\
\text { oxidation } \\
\text { (from B) }\end{array}$ & $\begin{array}{c}\text { F } \\
\text { Carbohydrate } \\
\text { oxidation } \\
\text { (indirect } \\
\text { calorimetry) }\end{array}$ \\
\hline $\operatorname{AGA}(n=8)$ & $7.55 \pm 0.56$ & $7.97 \pm 1.61$ & $0.42 \pm 1.65 \dagger$ & $4.51 \pm 0.60$ & $4.74 \pm 0.99$ & $6.62 \pm 1.23 \ddagger$ \\
\hline SGA $(n=8)$ & $8.16 \pm 0.65$ & $8.12 \pm 1.84$ & $-0.04 \pm 1.90 \dagger$ & $5.41 \pm 1.36$ & $5.33 \pm 1.56$ & $6.16 \pm 2.45$ \\
\hline
\end{tabular}

* Values are expressed as means \pm SD. None of the differences between AGA and SGA infants are significant (Wilcoxon).

$\uparrow$ Not significantly different from 0 at $p>0.05$.

$\ddagger$ Difference between carbohydrate oxidation $(\mathrm{F})$ and glucose oxidation (D and $\mathrm{E})$ significant at $p<0.05$ (Wilcoxon).

exogenous glucose intake only, and $4.74 \pm 0.99$ and $5.33 \pm 1.56$ $\mathrm{mg} / \mathrm{kg} \cdot \mathrm{min}$ when based on the $\mathrm{R}_{\mathrm{a}}$ (Table 4 ). In comparison, the carbohydrate oxidation rates calculated from the indirect calorimetry were $6.62 \pm 1.23$ and $6.16 \pm 2.45 \mathrm{mg} / \mathrm{kg} \cdot \mathrm{min}$ for AGA and SGA infants, respectively. The difference between carbohydrate oxidation, measured by indirect calorimetry, and glucose oxidation, measured by the stable isotope technique based on the $\mathrm{R}_{a}$, is significant at the $p<0.05$ level in AGA but not SGA infants.

\section{DISCUSSION}

Our study in preterm infants demonstrates that, as in adults, a glucose infusion causes a suppression of the endogenous glucose production. In fasting term infants, Denne and Kalhan (14) found an endogenous glucose production rate of $5 \mathrm{mg} / \mathrm{kg} \cdot \mathrm{min}$, whereas in our study with a glucose infusion rate of $8 \mathrm{mg} / \mathrm{kg}$. min (and continuous infusion of fat and amino acids) no significant endogenous glucose production could be measured (Table 4). During a glucose infusion of $5.6 \mathrm{mg} / \mathrm{kg} \cdot \mathrm{min}$ at postnatal d 1 to 2 in preterm AGA infants, without the simultaneous administration of amino acids or lipids, Cowett et al. (15) found an endogenous glucose production of $1-2 \mathrm{mg} / \mathrm{kg} \cdot \mathrm{min}$. However, in these studies, the glucose production may have been overestimated inasmuch as the glucose production that was negative was considered to be zero (15).

Our findings are consistent with those in a study in preterm AGA infants in which by the use of a clamp technique no endogenous glucose production could be determined (4). In the study of Denne and Kalhan (14), the $\mathrm{R}_{\mathrm{a}}$ was also measured using the plasma dilution of uniformly labeled glucose, whereas an "apparent" $\mathrm{R}_{\mathrm{a}}$ was calculated from the plasma dilution of glucose with a ${ }^{13} \mathrm{C}$ atom at the $\mathrm{C}-1$ position. In our study, the $\mathrm{R}_{\mathrm{a}}$ is calculated from the plasma dilution of $\left[\mathrm{U}-{ }^{13} \mathrm{C}\right]$ glucose and reflects glucose produced from both exogenous and endogenous sources. Unfortunately, because of ethical reasons, only one plasma sample at the plateau of ${ }^{13} \mathrm{CO}_{2}$ production could be taken. Recognizing the limitations of only one plasma sample, we still believe that this sample represents the $\mathrm{R}_{\mathrm{a}}$ for several reasons. First, the fact that TPN is given continuously over days before and during the study period results in a stability of the $R_{a}$ in these preterm infants under thermoneutral environment conditions. This stable condition is also reflected by the presence of normoglycemia in all plasma samples taken during these studies. Second, the fact that a stable plateau in the expired ${ }^{13} \mathrm{CO}_{2}$ was reached after 3-4 $\mathrm{h}$ supports the presence of a plateau of $\left[\mathrm{U}^{13} \mathrm{C}\right]$ glucose in plasma. Finally, the coefficient of variation of the determinations of glucose $m+6$ enrichment in plasma was only $2-6 \%$.

The absent endogenous glucose production during TPN in our study in comparison with the maintained production found in the study by Cowett et al. (3) may also be explained by the fact that in the latter study only glucose was infused. The addition of lipids may influence glucose production significantly as demonstrated by Bougneres (16). The absence of endogenous glucose production noted in our study supports the assumption that glucose oxidation can be calculated from exogenous sources only during high rates of glucose infusion, as described in previous studies $(2,17)$. Suppression of endogenous glucose production may, however, be incomplete under circumstances in which less glucose is given or glucose is the sole calorie source of the parenteral nutrition.

SGA newborn infants are at risk for hypoglycemia, a situation that may be caused by an impairment of the gluconeogenic pathway in the liver of these infants, demonstrated in man and in several experimental animal studies $(18,19)$. Our study, like that by Cowett et al. (3) in term infants, demonstrates no difference in the level of suppression of the glucose production during glucose infusion between AGA and SGA preterm infants.

The glucose oxidation is calculated from the plateau in expiratory ${ }^{13} \mathrm{CO}_{2}$, which is the end product of all ${ }^{13} \mathrm{C}$-labeled glucose that is oxidized. This includes not only glucose labeled at all six carbon atoms, but also glucose labeled at less than six carbon atoms. Therefore, the glucose oxidation based on the plateau in expiratory ${ }^{13} \mathrm{CO}_{2}$ and the $\mathrm{R}_{\mathrm{a}}$ from $\left[\mathrm{U}-{ }^{13} \mathrm{C}\right]$ glucose dilution in plasma might be an overestimation of the "true" oxidation. Because endogenous glucose production was absent in our study, an overestimation of the glucose oxidation is not likely.

Some factors determining the optimal glucose infusion rate during TPN have been studied in adults (20). When, in adults, a glucose infusion was increased from 4 to $7 \mathrm{mg} / \mathrm{kg} \cdot \mathrm{min}$, the glucose oxidation also increased, but a further increase to $9 \mathrm{mg}$ / $\mathrm{kg} \cdot \mathrm{min}$ was no longer followed by a significant increase in oxidation (20). It was postulated that, under the latter conditions, the infused glucose that is not directly oxidized is converted into fat as reflected by an increase in RQ and metabolic rate. Similarly, in a previous study in predominantly term newborn infants infused with glucose at rates of 10 to $15 \mathrm{mg} / \mathrm{kg} \cdot \mathrm{min}$, the differences between carbohydrate oxidation determined by indirect calorimetry and glucose oxidation measured by $\left[\mathrm{U}-{ }^{13} \mathrm{C}\right]$ glucose methodology were significant (2). In our study with a glucose infusion rate of $8 \mathrm{mg} / \mathrm{kg} \cdot \mathrm{min}$, a significant difference was seen in preterm AGA infants between the carbohydrate oxidation measured by indirect calorimetry and the glucose oxidation measured by stable isotopes. In fact, in some AGA infants, a negative fat oxidation was calculated, as shown by an RQ above unity. Frayn (21) has shown that the negative value obtained for fat oxidation during indirect calorimetry still quantitatively represents net fat oxidation, and equals total fat oxidation minus lipogenesis from carbohydrates. In the same study, it was demonstrated that, also at an RQ less than 1 , indirect calorimetry cannot distinguish between simultaneous fat oxidation and synthesis. The calculated carbohydrate oxidation may therefore be overestimated as suggested previously (2) and include carbohydrates apparently oxidized but in fact converted into fat. We therefore suggest a marked rate of lipogenesis from glucose in AGA infants that was not observed in SGA infants. Another explanation for the difference between glucose oxidation measured by tracer study and carbohydrate oxidation measured by indirect calorimetry could be intracellular glycogen oxidation. This seems to be less likely, inasmuch as both AGA and SGA 
infants were studied during comparable stable conditions, and no differences between glucose and carbohydrate oxidation were found in SGA infants.

In conclusion, our study demonstrates that if glucose is parenterally infused during TPN in AGA and SGA infants at $8 \mathrm{mg} /$ $\mathrm{kg} \cdot \min , 4.7-5.3 \mathrm{mg} / \mathrm{kg} \cdot \mathrm{min}$ is directly oxidized $(63-65 \%)$, and endogenous glucose production is absent. The glucose oxidation rate showed no significant difference from the carbohydrate oxidation rate measured by indirect calorimetry in SGA infants, but was significantly smaller than the carbohydrate oxidation rate found in AGA infants, possibly indicating increased lipogenesis from glucose in the latter group.

Acknowledgments. The authors thank S. C. Pellekaan, R.N., and the nursing staff, Division of Neonatology; I. H. T. Luijendijk and P. A. J. M. Adan, Research Laboratory, Department of Pediatrics, Sophia Children's Hospital, Rotterdam; I. E. Mulder, Research Laboratory, Department of Pediatrics, State University Groningen; and G. Nagel, C.K.C.L., University Hospital Groningen, The Netherlands, for expert technical assistance.

\section{REFERENCES}

1. Wolfe RR, Allsop JR, Burke JF 1979 Glucose metabolism in man: responses to intravenous glucose infusion. Metabolism 28:210-220

2. Sauer PJJ, Van Aerde JEE, Pencharz PB, Smith JM, Swyer PR 1986 Glucose oxidation rates in newborn infants measured with indirect calorimetry and $\mathrm{U}-{ }^{13} \mathrm{C}$ glucose. Clin Science 70:587-593

3. Cowett RM, Susa JB, Oh W, Schwartz R 1984 Glucose kinetics in glucoseinfused small for gestational age infants. Pediatr Res 18:74-79

4. Zarlengo KM, Battaglia FC, Fennessey P, Hay WW 1986 Relationship between glucose utilization rate and glucose concentration in preterm infants. Biol Neonate 49:181-189

5. Usher RH, McLean F 1969 Intrauterine growth of live-born caucasian infants at sea level: standards obtained from measurements in 7 dimensions of infants born between 25 and 44 weeks of gestation. J Pediatr 74:901-910
6. Ballard JL, Kazmaier W, Novak K, Driver M 1979 A simplified score for assessment of fetal maturation in newly born infants. J Pediatr 95:769-774

7. Spritzer R, Koolen AMP, Baerts W, Fetter WPF, Lafeber HN, Sauer PJJ 1988 A prolonged decline in the incidence of necrotizing enterocolitis after the introduction of a cautious feeding regime. Acta Paediatr Scand 77:909-911

8. Sauer PJJ, Dane HJ, Visser HKA 1984 Longitudinal studies on metabolic rate, heat loss and energy cost of growth in low birthweight infants. Pediatr Res 18:254-259

9. Kirsten WJ, Hesselius GU 1983 Rapid, automatic, high capacity Dumas determination of nitrogen. Microchem J 28:529-547

10. Lusk G 1924 Analysis of the oxidation of carbohydrate and fat. J Biol Chem $54: 41-42$

11. Van Aerde JEE, Sauer PJJ, Pencharz PB, Canagarayar U, Beesley J, Smith JM, Swyer PR 1985 The effect of energy intake and expenditure on the recovery of ${ }^{13} \mathrm{CO}_{2}$ in the neonate during a 4 hour primed constant infusion of $\mathrm{NaH}^{13} \mathrm{CO}_{3}$. Pediatr Res 19:806-810

12. Tserng KI, Kalhan SC 1983 Estimation of glucose carbon recycling and glucose turnover with U- ${ }^{13} \mathrm{C}$ glucose. Am J Physiol 245:476-482

13. Chapman TE 1989 Measurements of glucose production rates in babies and children using isotope dilution mass spectrometry. In: Baillie TA, Jones JR (eds) Synthesis and Applications of Isotopically Labelled Compounds 1988. Elsevier, Amsterdam, pp 163-169

14. Denne SC, Kalhan SC 1986 Glucose carbon recycling and oxidation in human newborns. Am J Physiol 251:71-77

15. Cowett RM, Oh W, Schwartz R 1983 Persistent glucose production during glucose infusion in the neonate. J Clin Invest 71:467-475

16. Bougneres PF 1988 The effect of lipid substrate oxidation on the neonatal production of glucose. Ann Pediatr (Paris) 35:449-453

17. Van Aerde JEE, Sauer PJJ, Pencharz PB, Smith JM, Swyer PR 1989 Effect of replacing glucose with lipid on the energy metabolism of newborn infants. Clin Sci 76:581-588

18. Haymond MH, Karl IE, Pagliara AS 1974 Increased gluconeogenic substrates in the small for gestational age infant. N Engl J Med 291:322-328

19. Lafeber HN, Jones CT, Rolph TP 1979 Some of the consequences of intrauterine growth retardation. In: Visser HKA (ed) Nutrition and Metabolism of the Fetus and Infant. Martinus Nijhoff Publishers, The Hague, pp 43-62

20. Wolfe RR, O’Donell TF, Stone MD, Richmand DA, Burke JF 1980 Investigation of factors determining the optimal glucose infusion rate in total parenteral nutrition. Metabolism 29:892-900

21. Frayn KN 1983 Calculation of substrate oxidation rates in vivo from gaseous exchange. J Appl Physiol 55:628-634 